\title{
Synthesis of Iron Sulfide Thin Films and Powders from New Xanthate Precursors
}

DOI:

10.1016/j.jcrysgro.2019.05.029

\section{Document Version}

Accepted author manuscript

Link to publication record in Manchester Research Explorer

\section{Citation for published version (APA):}

Almanqur, L., Alam, F., Whitehead, G., Vitorica-yrezabal, I., O'brien, P., \& Lewis, D. J. (2019). Synthesis of Iron Sulfide Thin Films and Powders from New Xanthate Precursors. Journal of Crystal Growth .

https://doi.org/10.1016/j.jcrysgro.2019.05.029

\section{Published in:}

Journal of Crystal Growth

\section{Citing this paper}

Please note that where the full-text provided on Manchester Research Explorer is the Author Accepted Manuscript or Proof version this may differ from the final Published version. If citing, it is advised that you check and use the publisher's definitive version.

\section{General rights}

Copyright and moral rights for the publications made accessible in the Research Explorer are retained by the authors and/or other copyright owners and it is a condition of accessing publications that users recognise and abide by the legal requirements associated with these rights.

\section{Takedown policy}

If you believe that this document breaches copyright please refer to the University of Manchester's Takedown Procedures [http://man.ac.uk/04Y6Bo] or contact uml.scholarlycommunications@manchester.ac.uk providing relevant details, so we can investigate your claim.

\section{OPEN ACCESS}




\title{
Synthesis of Iron Sulfide Thin Films and Powders from New Xanthate Precursors
}

Laila Almanqur, ${ }^{1,2}$ Firoz Alam, ${ }^{1,3}$ George Whitehead, ${ }^{1}$ Inigo Vitorica-yrezabal, ${ }^{1}$ Paul O’Brien. ${ }^{1,3}$ and David J. Lewis ${ }^{3 *}$

${ }^{1}$ School of Chemistry, University of Manchester, Oxford Road, Manchester, M13 9PL, UK.

${ }^{2}$ Department of chemistry, College of Science and Human studies, Majmaah University, 11952, Saudi Arabia

${ }^{3}$ School of Materials, University of Manchester, Oxford Road, Manchester, M13 9PL, UK.

Electronic Supplementary Information (ESI) available: Crystal data for CCDC reference numbers XXXXXX. See DOI: 10.1039/x0xx00000x

*corresponding author Dr. David J. Lewis

Email: david.lewis-4@manchester.ac.uk

\begin{abstract}
A series of novel alkylxanthato iron(III) precursors [Fe( $\left.\left.\mathrm{S}_{2} \mathrm{COR}\right)_{3}\right](\mathrm{R}=\mathrm{n}$-butyl, (1); 2-butyl, (2); 2-methoxyethyl, (3); and 2-ethoxyethyl (4)) have been synthesised and their single crystal X-ray structures have been studied. All as-synthesised complexes were used as singlesource precursors for the deposition of iron sulfide thin films as well as nanostructures using spin coating technique and solventless thermolysis respectively. Cubic pyrite was obtained using n-butyl xanthato iron(III) and 2-butyl xanthato iron(III) complexes in the temperature range of 200 to $300^{\circ} \mathrm{C}$. Structural and morphological investigations using XRD and SEM have been performed to ascertain the crystallinity and morphology of as-prepared thin films and nanostructures. The elemental composition was determined using energy dispersive $\mathrm{X}$ ray (EDX) spectroscopy. The optical band gaps of pyrite thin films produced by these methods were direct with estimated values in the range 1.6 to $2.3 \mathrm{eV}$.
\end{abstract}

\section{Introduction}

Semiconducting metal sulfides have excellent properties for optical, optoelectronic and electronic devices that have scientific and technological importance. ${ }^{1-4}$ Among the various iron chalcogenides, the iron sulfides $\left(\mathrm{Fe}_{\mathrm{x}} \mathrm{S}_{\mathrm{y}}\right)$ could be useful for sustainable energy applications as the constituent elements are abundant in the earth's crust and are mainly nontoxic. ${ }^{5}$ Iron 
sulfide has a variety of crystalline phases, which includes cubic pyrite $\left(\mathrm{FeS}_{2}\right)$, orthorhombic marcasite $\left(\mathrm{FeS}_{2}\right)$, pyrrhotite $\left(\mathrm{Fe}_{1-\mathrm{x}} \mathrm{S}\right)$, cubic spinel greigite $\left(\mathrm{Fe}_{3} \mathrm{~S}_{4}\right)$, smythite $\left(\mathrm{Fe}_{3} \mathrm{~S}_{4}\right)$, troilite$(\mathrm{FeS})$ and mackinawite $\left(\mathrm{Fe}_{1+\mathrm{x}} \mathrm{S}\right) \cdot{ }^{6-10}$ Of these phases, pyrite is considered to be an important transition metal sulfide due to its semiconducting properties, high light absorption across the visible range $\left(\sim 5 \times 10^{5} \mathrm{~cm}^{-1}\right)$ and its band gap energy of $0.95 \mathrm{eV} .{ }^{11-14}$ This material has been researched for a range of applications such as commercial lithium ion cells, solar cells and for catalysis. ${ }^{15-18}$ Furthermore, it has also been used in optoelectronic devices, storage devices, energy conversion and biomedical applications. ${ }^{19,20}$ Nanostructured pyrite has been produced with control of morphology, phases and size which are strongly influenced by reaction parameters such as precursor type, deposition temperature and synthesis method. Several approaches have been used for the deposition of iron sulfide thin films such as chemical spray pyrolysis, aerosol assisted chemical vapor deposition (AACVD), metal organic chemical vapor deposition (MOCVD) and low-pressure chemical vapor deposition (LPCVD). ${ }^{21-27}$ Furthermore, a wide range of single source precursors (SSPs) including dithiocarbamates, xanthates, thiosemicarbazone, thiobiuret and dithiobiuret have also been used for the deposition of iron sulfide thin films as well as to produce nanostructured materials. ${ }^{28-30}$ In addition, several methods have been utilized to synthesised iron sulfide nanostructures, such as hot injection method, solvothermal, hydrothermal and plasma assisted sulfurisation. ${ }^{31-36}$ Recently, we have reported the use of iron alkyl xanthate with short carbon chain lengths as SSPs for the preparation of thin films and nanocrystalline materials. ${ }^{37}$ These xanthate complexes produce the iron sulfides troilite $(\mathrm{FeS})$ and pyrrhotite $\left(\mathrm{Fe}_{1-\mathrm{x}} \mathrm{S}\right)$.

Herein, we report a direct route to high quality iron sulfide thin films and nanostructures of various morphologies at low temperatures from molecular precursor chemistry. The single crystal X-ray structures of all as-synthesised complexes are also reported. We focus on studying three main factors which may affect materials growth, deposition method, temperature and precursor type in order to exert control over the structural, phase purities, size and morphology of the produced iron sulfide thin films and nanomaterials.

\section{Experimental section}

\section{Chemicals and Instrumentation}

All chemicals were purchased from Sigma-Aldrich and used as received without further purification. Infrared spectra (IR) were recorded using a Specac single reflectance ATR instrument (in the range 4000-400 $\mathrm{cm}^{-1}$, resolution $4 \mathrm{~cm}^{-1}$ ). Melting points were recorded 
using a Barloworld SMP10 apparatus. Nuclear magnetic resonance (NMR) was obtained using a $400 \mathrm{MHz}$ Bruker instrument. Elemental analysis (EA) was performed by The University of Manchester micro-analytical laboratory. Thermogravimetric analysis (TGA) measurements were carried out by a Seiko SSC/S200 model under a heating rate of $10{ }^{\circ} \mathrm{C}$ $\min ^{-1}$ under nitrogen. Thin films were deposited on glass substrates using spin coating (Ossila, 24 V DC, 2.01 A). X-ray diffraction (XRD) measurements were carried out using a Bruker D8 Advance and a Bruker Xpert diffractometer with a $\mathrm{Cu}-\mathrm{K} \alpha$ radiation $(\lambda \sim 1.5406 \AA)$ with a step size of $0.02^{\circ}$. Scanning electronic microscopy (SEM) images were collected using a Philips XL30 FEG SEM. Films thickness was measured by stylus profilometry using a Bruker DektakXT system. UV-vis spectra were recorded using a Shimadzu UV-1800. Single crystal X-ray diffraction data for complexes were obtained using a dual source Rigaku FR-X rotating anode diffractometer, using $\mathrm{MoK}_{\alpha}$ wavelength at $150 \mathrm{~K}$ and reduced using a CrysAlisPro 171.39.30c. The structures were refined using Shelx-2016, implemented through Olex 2 v1.2.9. ${ }^{38-40}$

\section{Synthesis of Potassium n-Butylxanthate}

The ligand was synthesised by the method described in literature. ${ }^{41}$ Briefly, carbon disulfide $\left(\mathrm{CS}_{2}\right)(6.78 \mathrm{~g}, 5.38 \mathrm{ml}, 89.12 \mathrm{mmol})$ was added dropwise to a mixture of potassium hydroxide $(5 \mathrm{~g}, 89.12 \mathrm{mmol})$ in $\mathrm{n}$-butanol $(60 \mathrm{~mL})$ with stirring for $30 \mathrm{~min}$. A yellow precipitate was then collected and purified by recrystallization in acetone to give $\left[\mathrm{K}\left(\mathrm{S}_{2} \mathrm{CO}^{\mathrm{n}} \mathrm{Bu}\right)\right]$. Yield $16.0 \mathrm{~g}(96 \%)$. Mp: $116-119^{\circ} \mathrm{C}$. Anal. calc. for $\mathrm{C}_{5} \mathrm{H}_{9} \mathrm{KOS}_{2}(\%)$ : C 31.90, H 4.82, S 33.99, K 20.78; found: C 31.72, H 4.65, S 33.45, K 21.66. FT-IR ( $v_{\max } / \mathrm{cm}^{-}$ ${ }^{1}$ ): 2958 (m), 2942(w), 2869 (w), 1460 (m), 1444 (w), 1260 (s), 1148 (m), 1172 (m), 1053 (m), 1014(m), 747 (m), 669 (s). ${ }^{1} \mathrm{H}$ NMR (400 MHz, $\left.\mathrm{D}_{2} \mathrm{O}\right): \delta$ ppm 0.89 (t, 3H, $\left.\mathrm{CH}_{3}\right), 1.43$ (m, $\left.2 \mathrm{H}, \mathrm{CH}_{2}\right), 1.67\left(\mathrm{~m}, 2 \mathrm{H}, \mathrm{CH}_{2}\right), 4.43\left(\mathrm{t}, 2 \mathrm{H}, \mathrm{CH}_{2}\right)$.

\section{Synthesis of Potassium 2-Butylxanthate}

$\left.\mathrm{K}\left(\mathrm{S}_{2} \mathrm{CO}^{2} \mathrm{Bu}\right)\right]$ was synthesized in a same way as potassium n-butylxanthate except replacing n-butanol with 2-butanol. The yield was (16.3 g 97.6 \%), Mp: $110-123{ }^{\circ} \mathrm{C}$. Anal. calc. for $\mathrm{C}_{5} \mathrm{H}_{9} \mathrm{KOS}_{2}(\%)$ : C 31.90, H 4.82, S 33.99, K 20.78; found: C 31.72, H 4.65, S 33.45, K 21.66. FT-IR $\left(v_{\max } / \mathrm{cm}^{-1}\right)$ : $2966(\mathrm{~m}), 2929(\mathrm{w}), 2871(\mathrm{w}), 1460(\mathrm{~m}), 1455(\mathrm{~m}), 1376(\mathrm{~m})$, 1178 (m), $1140(\mathrm{~m}), 1110$ (s). ${ }^{1} \mathrm{H}$ NMR (400 MHz, D $\left.2 \mathrm{O}\right): \delta \mathrm{ppm} 0.85$ (t, 3H, CH $\left.\mathrm{CH}_{3}\right), 1.23$ (d, $\left.3 \mathrm{H}, \mathrm{CH}_{3}\right), 1.60\left(\mathrm{~m}, 2 \mathrm{H}, \mathrm{CH}_{2}\right), 5.33(\mathrm{~m}, \mathrm{H}, \mathrm{CH})$. 


\section{Synthesis of Potassium 2-Methoxyethylxanthate}

$\left[\mathrm{KS}_{2} \mathrm{CO}-\left(\mathrm{CH}_{2}\right)_{2} \mathrm{OMe}\right]$ was synthesized according to the reported literature. ${ }^{42,43}$ In typical reaction, $\mathrm{KOH}(5 \mathrm{~g}, 89.12 \mathrm{mmol})$ was dissolved in a mixture of 2-methoxyethanol $(50 \mathrm{ml})$ and distilled water $(20 \mathrm{ml})$ at room temperature. A drop-wise addition of $\mathrm{CS}_{2}(6.78 \mathrm{~g}, 5.38$ $\mathrm{ml}, 89.12 \mathrm{mmol}$ ) into $\mathrm{KOH}$ solution was performed with stirring. A yellow precipitate rapidly formed which then collected by vacuum filtration and washed several times with petroleum ether. The crude product was recrystallized from 2-methoxyethanol. Yield $16.2 \mathrm{~g}$ (96\%), Mp: 201-204 ${ }^{\circ} \mathrm{C}$. Anal. calc. for $\mathrm{C}_{4} \mathrm{H}_{7} \mathrm{KO}_{2} \mathrm{~S}_{2}$ (\%): C 25.25, H 3.71, S 33.69, K 20.57; found: C 25.48, H 3.67, S 33.51, K 20.93. FT-IR $\left(v_{\max } / \mathrm{cm}^{-1}\right)$ : $2970(\mathrm{~m}), 2937(\mathrm{w}), 2883(\mathrm{w}), 1673(\mathrm{~s})$, 1455 (m), 1592 (s), 1295 (s), $1210(\mathrm{~s}), 997$ (s). ${ }^{1} \mathrm{H}$ NMR (400 MHz, D $\left.2 \mathrm{O}\right) \delta$ (ppm) =3.37 (s, $\left.3 \mathrm{H}, \mathrm{OCH}_{3}\right), 3.75\left(\mathrm{t}, 2 \mathrm{H}, \mathrm{CH}_{2} \mathrm{CH}_{2} \mathrm{O}\right), 4.50\left(\mathrm{t}, 2 \mathrm{H}, \mathrm{CH}_{2} \mathrm{CH}_{2} \mathrm{O}\right)$.

\section{Synthesis of Potassium 2-Ethoxyethylxanthate}

$\left[\mathrm{K}\left(\mathrm{S}_{2} \mathrm{CO}-\left(\mathrm{CH}_{2}\right)_{2} \mathrm{OEt}\right)\right]$ was synthesized in a same way as potassium n-butylxanthate except replacing 2-methoxyethanol with 2-ethoxyethanol. Yield $17.6 \mathrm{~g}$ (97\%), Mp: 160-180 ${ }^{\circ} \mathrm{C}$. Anal. calc. for $\mathrm{C}_{5} \mathrm{H}_{9} \mathrm{KO}_{2} \mathrm{~S}_{2}(\%)$ : C 29.40, H 4.44, S 31.33, K 19.16; found: C 29.27, H 4.37, S 30.86, K 19.64. FT-IR ( $\left.\mathrm{cm}^{-1}\right)$ : 2972 (w), 2859 (w), 1443(m), 1421(w), 1290 (w), 1246 (w), 1107(m), 1053 (s), 934 (w), $826(\mathrm{w}), 795$ (w). ${ }^{1} \mathrm{H}$ NMR (400 MHz, D $\left.2 \mathrm{O}\right) \delta(\mathrm{ppm})=1.17$ (t, $\left.3 \mathrm{H}, \mathrm{CH}_{3}\right), 3.60\left(\mathrm{~m}, 2 \mathrm{H}, \mathrm{CH}_{2}\right), 3.80\left(\mathrm{t}, 2 \mathrm{H}, \mathrm{CH}_{2} \mathrm{CH}_{2} \mathrm{O}\right), 4.53\left(\mathrm{t}, 2 \mathrm{H}, \mathrm{CH}_{2} \mathrm{CH}_{2} \mathrm{O}\right)$.

\section{Synthesis of Iron (III) n-Butyl xanthate (1)}

The complex was synthesized according to the reported literature. ${ }^{41}$ Briefly, an aqueous solution of iron (III) chloride $\left(\mathrm{FeCl}_{3}\right)(1.4 \mathrm{~g}, 8.8 \mathrm{mmol}, 1.0$ eq. $)$ was added dropwise into an aqueous solution potassium n-butyl xanthate (5 g, $26.5 \mathrm{mmol}, 3.0$ eq.) with stirring continued for $30 \mathrm{~min}$ post-addition. The black crude product was collected by suction filtration and washed with distilled water. Shiny black crystals of the title product were recrystallized from chloroform at $-20{ }^{\circ} \mathrm{C}$. Yield $3.5 \mathrm{~g}(80 \%)$. Mp: $70-79{ }^{\circ} \mathrm{C}$. Anal. calc. for $\mathrm{C}_{15} \mathrm{H}_{27} \mathrm{FeO}_{3} \mathrm{~S}_{6}(\%)$ : Calc. C 35.79, H 5.41, S 38.15, Fe 11.11; found: C 35.46, H 5.33, S 37.39,Fe 10.99. FT-IR $\left(\mathrm{cm}^{-1}\right)$ : $2957(\mathrm{~m}), 2920(\mathrm{w}), 2871(\mathrm{w}), 1744(\mathrm{w}), 1460(\mathrm{~m}), 1384(\mathrm{~m}), 1250(\mathrm{~s}), 1207$ (s), 1141 (m), 1115 (s), 1010 (s).

\section{Synthesis of Iron (III) 2-Butyl xanthate (2)}

A similar method was used for the synthesis of $\left[\mathrm{Fe}\left(\mathrm{S}_{2} \mathrm{CO}_{2} \mathrm{Bu}\right)_{3}\right]$ using 3.0 eq. of potassium 2-butylxanthate. The crude product was recrystallized from chloroform at $-20^{\circ} \mathrm{C}$. Yield 4.1 
g (94\%). Mp: 82-90 ${ }^{\circ} \mathrm{C}$ Anal. calc. for $\mathrm{C}_{15} \mathrm{H}_{27} \mathrm{FeO}_{3} \mathrm{~S}_{6}$ (\%): Calc C 35.79, H 5.41, S 38.15, Fe 11.11; found: C 35.93, H 5.41, S 38.14,Fe 11.14. FT-IR (cm $\left.{ }^{-1}\right): 2970$ (s), 2933 (m), 2875 (w), 1455 (m), 1377 (m), 1240 (s), $1120(\mathrm{~m})$.

\section{Synthesis of Iron (III) 2-Methoxyethylxanthate (3)}

The synthesis of $\left[\mathrm{Fe}\left(\mathrm{S}_{2} \mathrm{CO}\left(\mathrm{CH}_{2}\right)_{2} \mathrm{OMe}\right)_{3}\right]$ was done according to complex (1), using the potassium 2-methoxyethylxanthate. Yield 4.0g (91\%). Mp: 140-158 ${ }^{\circ} \mathrm{C}$. Anal. calc. for $\mathrm{C}_{12} \mathrm{H}_{21} \mathrm{FeO}_{6} \mathrm{~S}_{6}(\%)$ : Calc C 28.30, H 4.16, S 37.70, Fe 10.98; found: C 28.51, H 54.22, S 37.35, Fe 10.72. FT-IR ( $\left.v_{\max } / \mathrm{cm}^{-1}\right): 2983(\mathrm{~m}), 2886(\mathrm{w}), 2817(\mathrm{w}), 1745(\mathrm{w}), 14552(\mathrm{~m})$, 1367 (s), 1254 (s), $1124(\mathrm{~m})$.

\section{Synthesis of Iron (III) 2-Ethoxyethylxanthate (4)}

The synthesis of $\left[\mathrm{Fe}\left(\mathrm{S}_{2} \mathrm{CO}\left(\mathrm{CH}_{2}\right)_{2} \mathrm{OEt}\right)_{3}\right]$ was done according to complex (1), using the potassium 2-ethoxyethylxanthate. Yield $3.6 \mathrm{~g}$ (80\%). Mp: 127-130 ${ }^{\circ} \mathrm{C}$. Anal. calc. for $\mathrm{C}_{15} \mathrm{H}_{27} \mathrm{FeO}_{6} \mathrm{~S}_{6}(\%)$ :C 32.68, H 4.94, S 34.82, Fe 10.14; found: C 32.66, H 4.94, S 33.26,Fe 9.84. FT-IR ( $\left.\mathrm{cm}^{-1}\right)$ : 2972 (m), 2872 (m), 1448 (m), 1384 (m), 1353 (m), 1239 (s), 1036 (s).

\section{Preparation of iron sulfide thin films and powders}

Iron sulfide thin films were deposited on glass substrates. The glass substrates were cleaned ultrasonically in isopropanol, distilled water and finally with acetone and allowed to dry prior to use. The deposition was done using spin coating technique. In a typical deposition process, $0.13 \mathrm{~g}$ of precursor was dissolved in $0.5 \mathrm{ml}$ of chloroform to form clear solution, which was dropped on glass substrate at room temperature and rotated at $1400 \mathrm{rpm}$ for $30 \mathrm{sec}$ to make thin films of the precursor. The films were annealed in tube furnace at different temperatures $\left(200-300{ }^{\circ} \mathrm{C}\right.$ ) under nitrogen atmosphere for an hour to produce iron sulfide thin films.

The iron sulfide powders were synthesized using solventless thermolysis (melt method). Briefly, $0.4 \mathrm{~g}$ of solid precursor was placed in a ceramic boat in a tube furnace and then heated at the desired temperatures $\left(200-300{ }^{\circ} \mathrm{C}\right)$ in an inert atmosphere $\left(\mathrm{N}_{2}\right)$ for an hour.

\section{Results and discussion}

\section{Thermogravimetric analysis (TGA)}

Thermal decomposition of iron(III) xanthates complexes (1) - (4) were evaluated by thermogravimetric analysis (TGA) as shown in Figure 1. The precursors were heated from 
50 to $600{ }^{\circ} \mathrm{C}$ under nitrogen atmosphere. Complexes (1) and (2) decomposed in two steps with a rapid weight loss between 120 to $200{ }^{\circ} \mathrm{C}$. The solid decomposition residue amounts to 22 and $20 \%$, respectively, which is commensurate with decomposition to $\mathrm{FeS}_{2}$ (theoretically ca. 23\%). A gradual decomposition between 200 to $300{ }^{\circ} \mathrm{C}$ is then observed for both complexes with weights of final residues of $19 \%$ and $19 \%$ of the original mass which is in good agreement with calculated values for FeS $19 \%$ and 19\%, respectively for (1) and (2). Similar thermal decomposition behaviour was observed for complex (3) with final residue amount of 24\%, which is corresponds to FeS (theoretically ca. 24\%). In contrast, complex (4) shows slightly different decomposition behaviour, it shows multi-step decomposition with a final residue amount of $22 \%$, which is in agreement with the calculated value of $21 \%$ for $\mathrm{FeS}_{2}$.

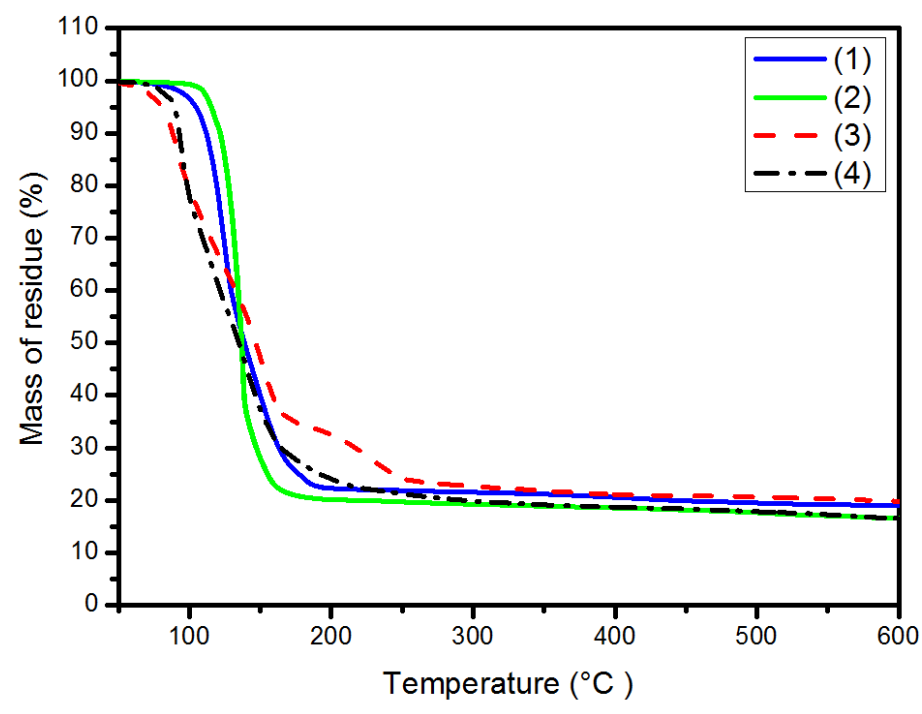

Figure 1. Thermogravimetric analysis (TGA) of complexes $\left[\mathrm{Fe}\left(\mathrm{S}_{2} \mathrm{CO}^{\mathrm{n}} \mathrm{Bu}\right)_{3}\right]$, (1), $\left[\mathrm{Fe}\left(\mathrm{S}_{2} \mathrm{CO}^{2} \mathrm{Bu}\right)_{3}\right]$ (2), $\left[\mathrm{Fe}\left(\mathrm{S}_{2} \mathrm{CO}-\left(\mathrm{CH}_{2}\right)_{2} \mathrm{OMe}\right)_{3}\right]$ (3) and $\left[\mathrm{Fe}\left(\mathrm{S}_{2} \mathrm{CO}-\right.\right.$ $\left.\left.\left(\mathrm{CH}_{2}\right)_{2} \mathrm{OEt}\right)_{3}\right]$ (4).

\section{Single-crystal X-ray structures of Fe complexes}

All four complexes adopt distorted octahedral coordination arrangement around the centre of iron ion with a six sulfur $\left(\mathrm{S}_{6}\right)$ donor set. Each iron ion is chelated by three bidentate xanthate ligands (Figure 2). The complexes (1), (2) and (3) were crystallized in the monoclinic system with space group of $P 21 / \mathrm{n}, P 21$ and $p 21 / \mathrm{n}$, respectively. Whereas, the complex (4) 
crystallized in the triclinic system with a space group of P-1. The structural refinement data, selected bond lengths and angles are summarized in the ESI Table (S1-S6). Relatively little variation was observed in the Fe-S bond length across the series, which are in the range

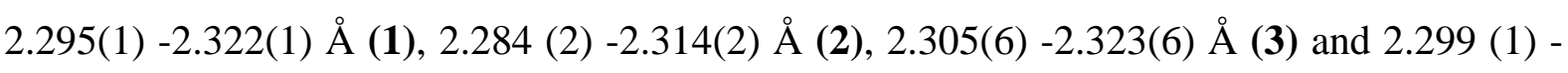
2.305(1) $\AA$ (4) for each of the complexes.

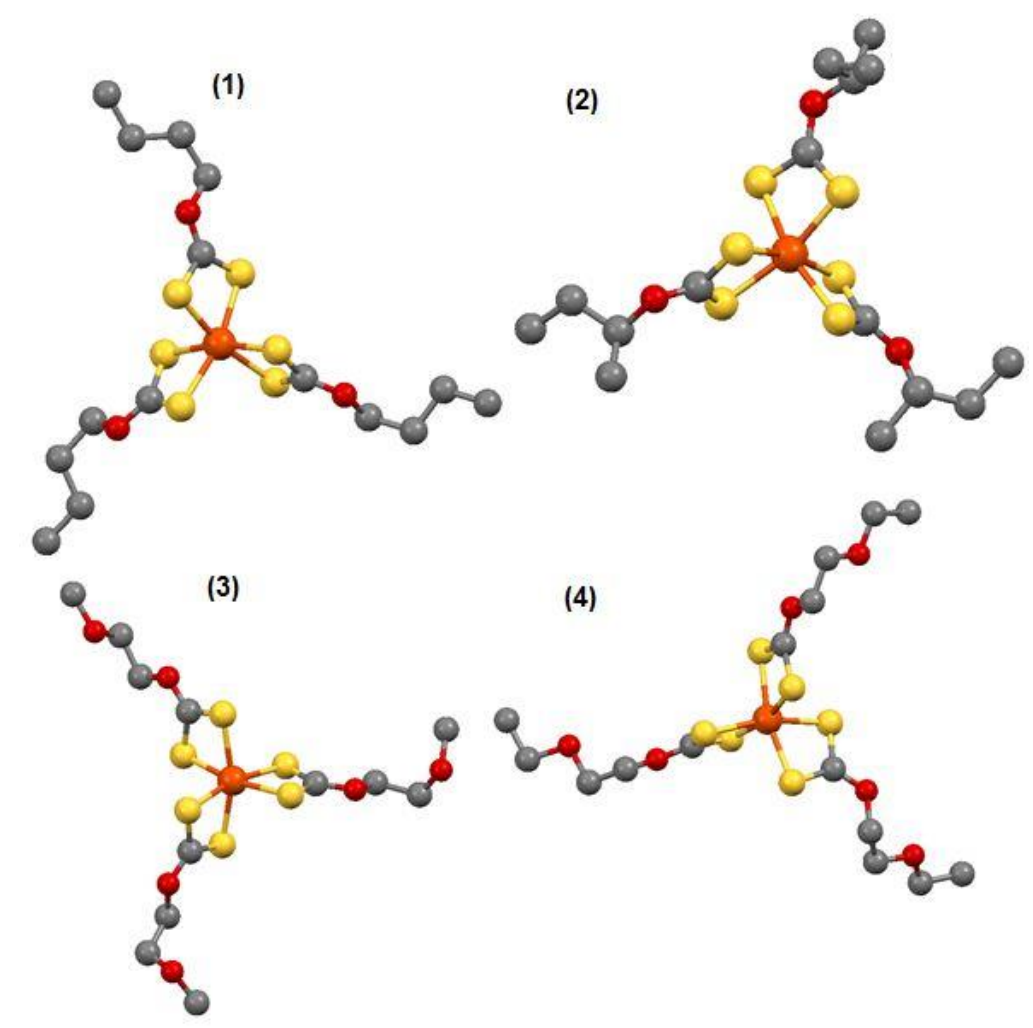

Figure 2. X-ray single crystal structures of complexes (1), (2), (3) and (4). Yellow spheres = sulfur, orange spheres $=$ iron, red spheres $=$ oxygen, grey spheres $=$ carbon .

\section{Iron sulfide thin films}

Iron disulfide $\left(\mathrm{FeS}_{2}\right)$ thin films were prepared using low-cost spin-coating method. We have chosen this method because it is unique and efficient to deposit thin films by simple and low fabrication costs route with control over thickness. Pyrite $\left(\mathrm{FeS}_{2}\right)$ thin films were deposited on the substrates using chloroform solution of iron alkyl xanthate precursor (1) - (4).

According to TGA results, the complexes decompose completely between $180{ }^{\circ} \mathrm{C}$ to $190{ }^{\circ} \mathrm{C}$. So the annealing temperatures were varied between 200 and $300{ }^{\circ} \mathrm{C}$. The films were prepared by coating glass slides with the precursor solution, followed by annealing at three different 
temperatures of 200,250 and $300{ }^{\circ} \mathrm{C}$ for $1 \mathrm{~h}$ in order to study the effect of growth temperatures on obtained materials. The resulting films were uniform black thin films at all the growth temperatures. The thickness measurement of pyrite films from complex (1) deposited at 200,250 and $300{ }^{\circ} \mathrm{C}$ was 337,355 and $370 \mu \mathrm{m}$ respectively (ESI Table S7).

The phase purity and crystal structures of iron sulfide thin films were identified using powder $\mathrm{X}$-ray diffraction ( $\mathrm{p}-\mathrm{XRD})$. The $\mathrm{p}-\mathrm{XRD}$ pattern of iron disulfide thin films prepared using a spin coated chloroform solution of complexes (1) and (2) are presented in (Figure 3 and ESI Figure S1). The XRD patterns, showed the formation of phase-pure $\mathrm{FeS}_{2}$ thin films at all annealing temperatures between 200 to $300{ }^{\circ} \mathrm{C}$ with no additional peaks of any impurities or other phases. The two major peaks at $2 \theta=28.58^{\circ}$ and $58.86^{\circ}$ are assigned to the (111) and (222) reflections of cubic pyrite $\left(\mathrm{FeS}_{2}\right)$ ICCD 01-089-3057) (ESI Figure S3). Growth temperature does not affect the phase of iron disulfide for complexes (1) and (2), suggesting that pyrite is a kinetic product from the decomposition of these precursors. This is in contrast to previous studies with short chain xanthates that produced troilite and pyrrhotite and allows access to new phases by judicious precursor choice.

The $\mathrm{p}$-XRD pattern of iron sulfide thin films prepared using complexes (3) and (4) are shown in (Figure 4 and ESI Figure S5). The major diffraction peaks with reflections of (111), (211), (221) and (222) corresponds to cubic pyrite while a minor peak at $66.4^{\circ}$ corresponds to orthorhombic marcasite phase $\left(\mathrm{FeS}_{2}\right)$ (ICDD. No. 00-003-0799). It is clear from the p-XRD patterns of films deposited from precursors (1) and (2) that thin films show only two peaks which indicated that the preferred orientation along the (111) and (222) planes under all the deposition conditions. Also, the thin films growth from precursors (3) and (4) show variation on peaks intensity comparing with the standard pattern which indicates to the preference orientation for the obtained crystallites. This behaviour of crystallite that has preferred orientation have been noticed with lead sulfide $(\mathrm{PbS})$ thin films deposited by AACVD method. ${ }^{44}$ This suggests that the substrate under these conditions exerts control over the nucleation and growth of iron sulfide thin films. The p-XRD shows sharp and narrow peaks which attributed to high crystallinity of the thin films.

Commonly, the formation of pyrite is potentially accompanied by marcasite impurities, ${ }^{45}$ and indeed these are observed when complexes (3) and (4) were used as precursors to deposit thin films. However, the purity of pyrite could be controlled by selection of precursor type which has influence on purity of pyrite phase as shown in results obtained from thin films deposited using complex (1) and (2), which show a pure pyrite phase. 
The micro and nanoscale morphology of iron sulfide thin films were studied by scanning electron microscopy (SEM). Micrographs of $\mathrm{FeS}_{2}$ thin films deposited by spin coating method from complexes (1) and (2) at growth temperatures of 200,250 and $300{ }^{\circ} \mathrm{C}$ are shown in Figure 5(1a-1d) and ESI Figure S7. Cubic crystallites with an average size range between $38 \mathrm{~nm}$ to $180 \mathrm{~nm}$ (size increasing with temperature) were observed in all samples produced from thermal decomposition of complexes (1) and (2). Small crystallites with no defined morphology were obtained at all deposition temperatures for pyrite thin films prepared using precursor (3) as shown in Figure 5 (2a, 2b) and ESI Figure S8. Semi-cubic crystallites were obtained at all deposition temperatures when complex (4) is used as precursor (Fig. 5 (2c-2d)) and ESI Figure S5.

Elemental analysis using EDX spectroscopy of the films prepared using complexes (1) to (4) agreed well with the expected 1:2 Fe: S stoichiometry of pyrite (ESI Table S8). Variation in the morphological properties of the resulting films suggests that the type of precursors used in deposited thin films have an important role on controlling microstructure, which can be seen in Figure 5.
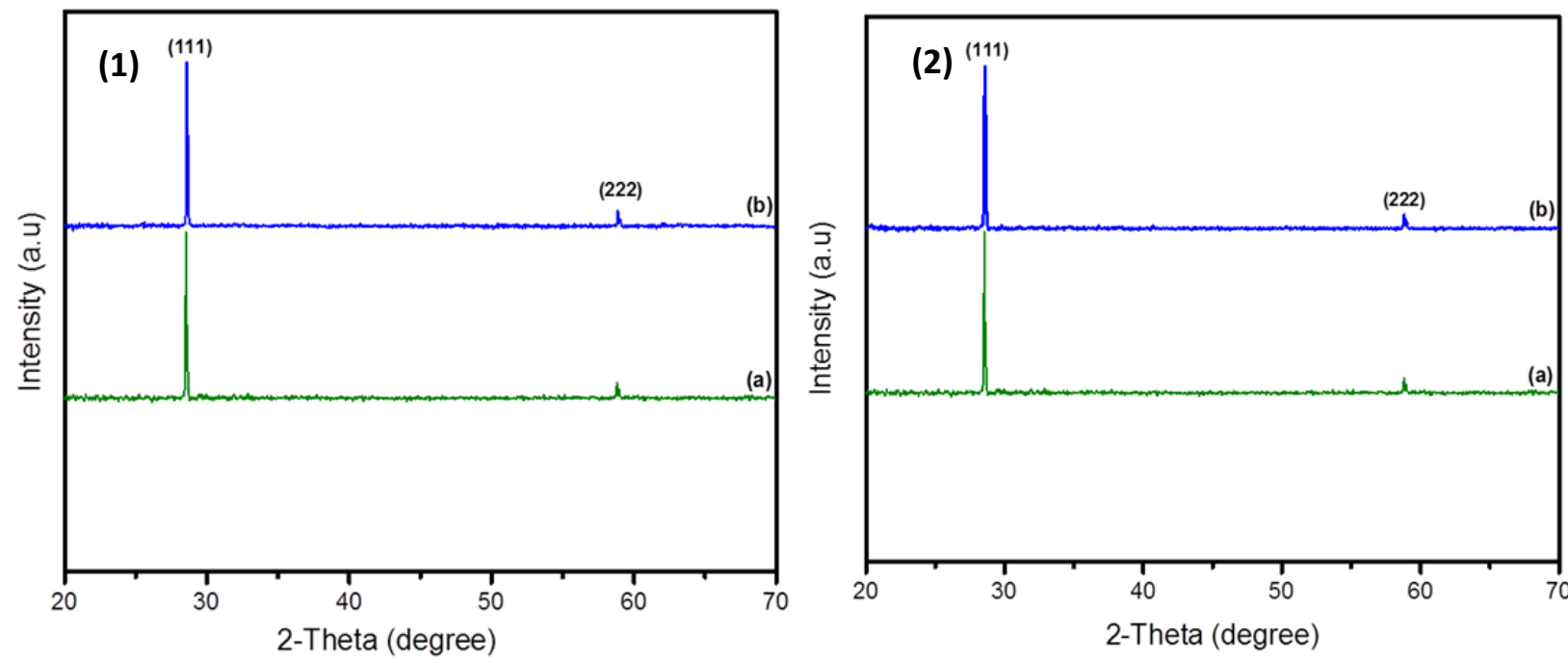

Figure 3. Powder X-ray diffraction (PXRD) patterns of the iron sulfide thin films obtained by spin coating using $\left[\mathrm{Fe}\left(\mathrm{S}_{2} \mathrm{CO}^{\mathrm{n}} \mathrm{Bu}\right)_{3}\right](1)$ and $\left[\mathrm{Fe}\left(\mathrm{S}_{2} \mathrm{CO}^{2} \mathrm{Bu}\right)_{3}\right]$ (2), followed by annealing under nitrogen at $250^{\circ} \mathrm{C}(\mathrm{a})$ and $300^{\circ} \mathrm{C}(\mathrm{b})$ for $60 \mathrm{~min}$. 

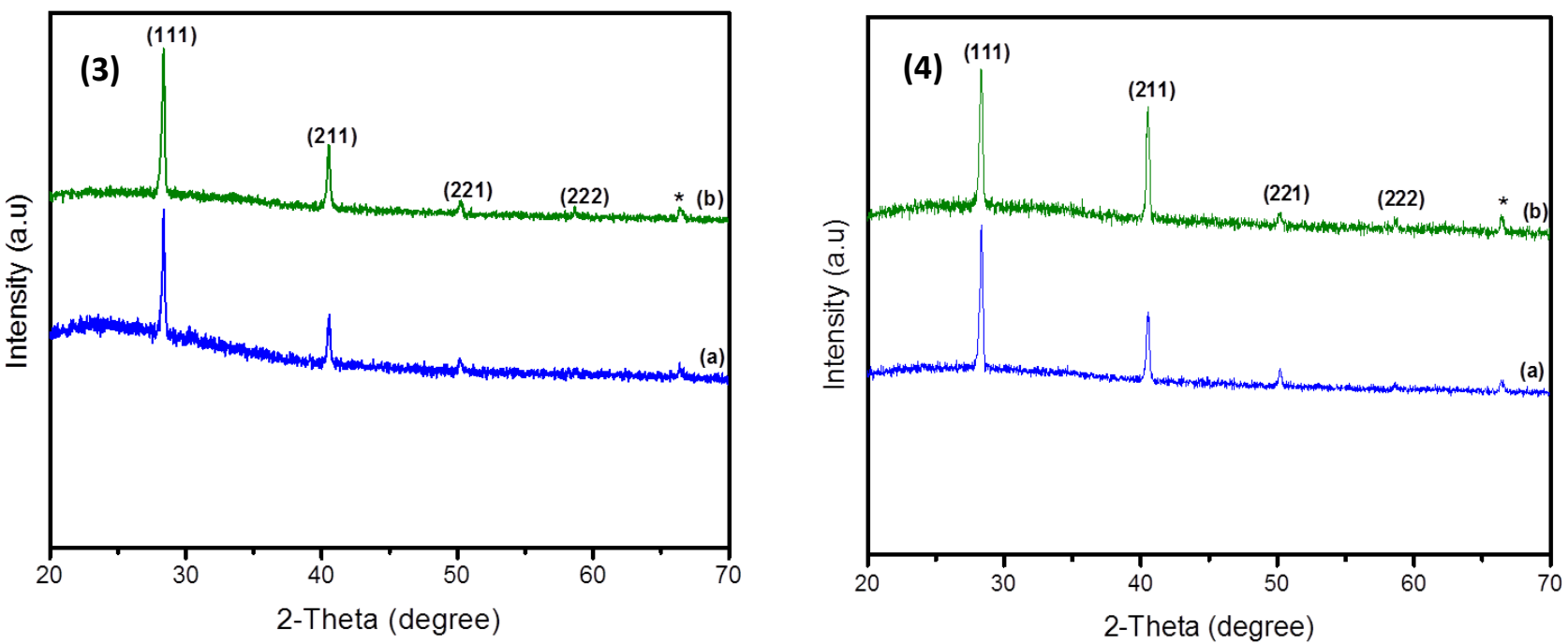

Figure 4. PXRD patterns of the iron sulfide thin films obtained by spin coating $\left[\mathrm{Fe}\left(\mathrm{S}_{2} \mathrm{CO}-\left(\mathrm{CH}_{2}\right)_{2} \mathrm{OMe}\right)_{3}\right]$ (3) and $\left[\mathrm{Fe}\left(\mathrm{S}_{2} \mathrm{CO}-(\mathrm{CH})_{2} \mathrm{OEt}\right)_{3}\right](4)$, followed by annealing under nitrogen at $250^{\circ} \mathrm{C}$ (a) and $300^{\circ} \mathrm{C}$ (b) for $60 \mathrm{~min}$. The asterisk symbols $\left({ }^{*}\right)$ correspond to reflections from orthorhombic marcasite (ICDD: 00 003-0799).
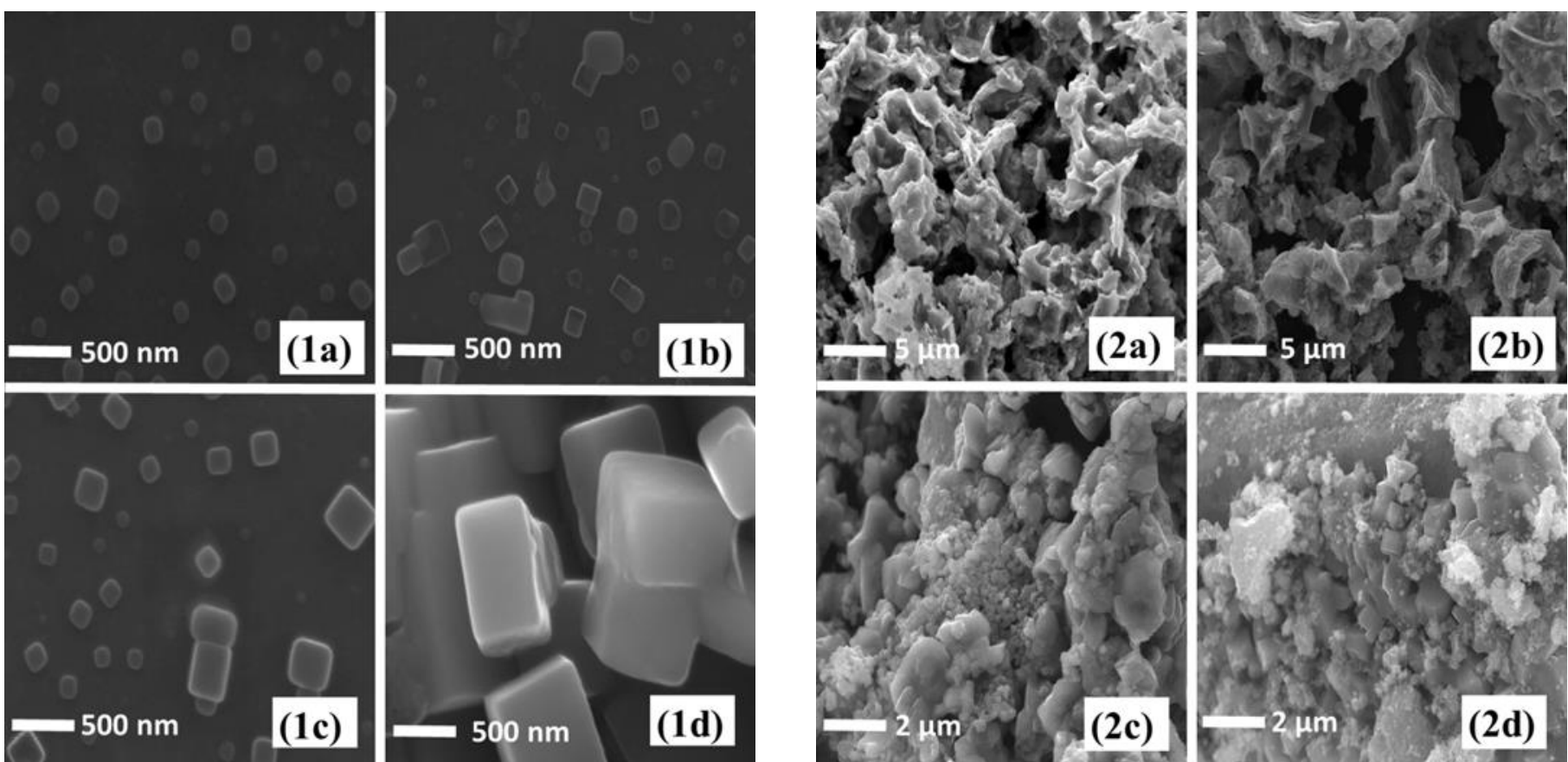

Figure 5. SEM images of iron sulfide thin films by spin coating method from $\left[\mathrm{Fe}\left(\mathrm{S}_{2} \mathrm{CO}^{n} \mathrm{Bu}\right)_{3}\right](1 \mathrm{a})$ at $250^{\circ} \mathrm{C}$ and $(1 \mathrm{~b})$ at $300{ }^{\circ} \mathrm{C},\left[\mathrm{Fe}\left(\mathrm{S}_{2} \mathrm{CO}{ }^{2} \mathrm{Bu}\right)_{3}\right]$ (1c) at $250^{\circ} \mathrm{C}$ and $(1 \mathrm{~d})$ at $300{ }^{\circ} \mathrm{C},\left[\mathrm{Fe}\left(\mathrm{S}_{2} \mathrm{CO}-\left(\mathrm{CH}_{2}\right)_{2} \mathrm{OMe}\right)_{3}\right](2 \mathrm{a})$ at $250^{\circ} \mathrm{C}$ and $(2 \mathrm{~b})$ at $300^{\circ} \mathrm{C}$, and $\left[\mathrm{Fe}\left(\mathrm{S}_{2} \mathrm{CO}-\left(\mathrm{CH}_{2}\right)_{2} \mathrm{OEt}\right)_{3}\right](2 \mathrm{c})$ at $250^{\circ} \mathrm{C}$ and $(2 \mathrm{~d})$ at $300^{\circ} \mathrm{C}$. 

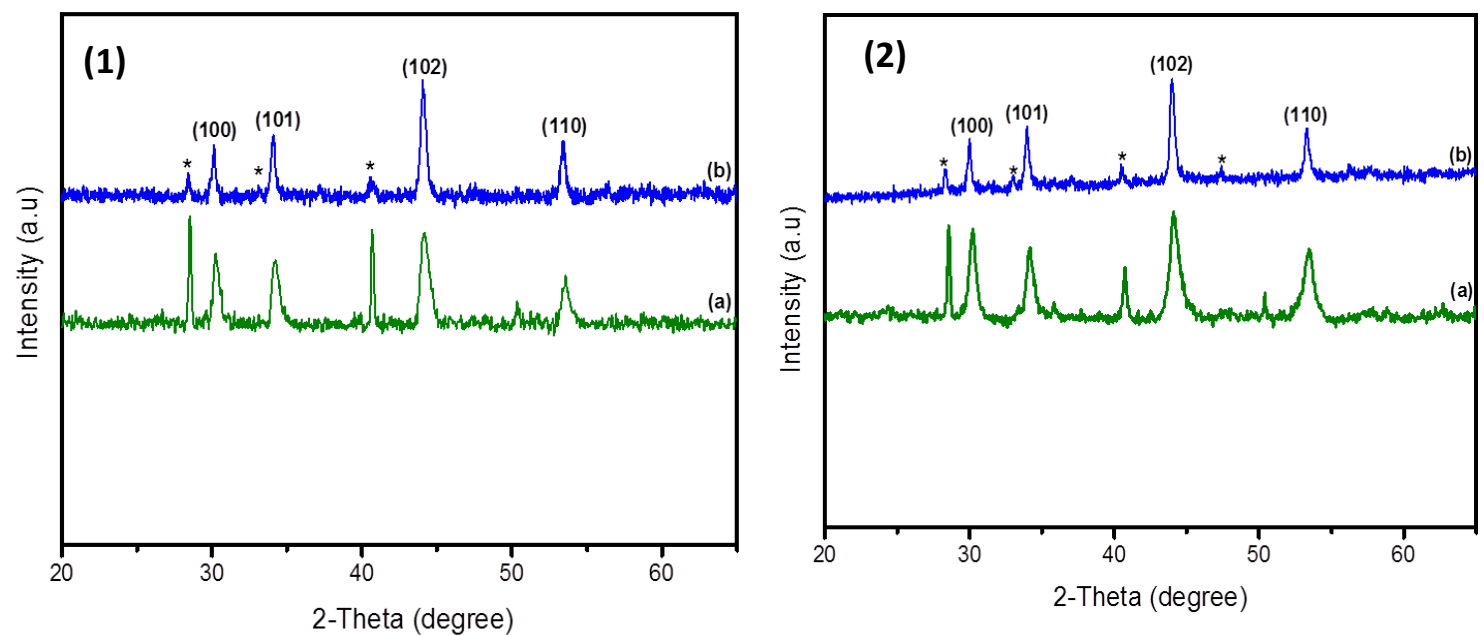

Figure 6. Powder X-ray diffraction ( $p$-XRD) patterns of the iron sulfide nanostructure obtained by solventless thermolysis method using $\left[\mathrm{Fe}\left(\mathrm{S}_{2} \mathrm{CO}^{\mathrm{n}} \mathrm{Bu}\right)_{3}\right],(\mathbf{1})$ and $\left[\mathrm{Fe}\left(\mathrm{S}_{2} \mathrm{CO}^{2} \mathrm{Bu}\right)_{3}\right]$ (2), annealing under nitrogen at $250{ }^{\circ} \mathrm{C}(\mathrm{a})$ and $300{ }^{\circ} \mathrm{C}(\mathrm{b})$ for $60 \mathrm{~min}$. The asterisk symbols $\left(^{*}\right)$ correspond to reflections from cubic pyrite (ICDD: 01-0893057).

\section{Iron sulfide nanostructures}

This work includes preparation of iron sulfide nanostructures in the absence of any solvent. Thermolysis is a low-cost and simple route toward the development of semiconductor materials. Commonly, this method produces high yields in comparison with other method such as hot injection.

All the complexes were used as single molecular precursors to synthesise iron sulfide thin films as well as nanostructures using spin coating technique and solventless thermolysis method. The p-XRD patterns of iron sulfide nanomaterial prepared using complexes (1) and (2) show the formation of phase-separated pyrrhotite (ICDD: 01-075-0600) (ESI Figure S5) and cubic pyrite at all growth temperatures (Figure 6 and ESI Figure S4). The (100), (101), (102) and (110) reflections of hexagonal pyrrhotite are superimposed on the diffraction pattern of cubic pyrite $\left(\mathrm{FeS}_{2}\right)$. These data also show that by increasing the synthesis temperature to $300{ }^{\circ} \mathrm{C}$, the pyrrhotite phase becomes dominant, which suggests that in this case, the choice of phase could be dictated by judicious choice of reaction temperature. The p-XRD patterns for iron sulfide powders obtained using complexes (3) and (4) are shown in Figure 5 and ESI Figure S6. The presence of phase separated cubic greigite and cubic pyrite 
phases are observed at all growth temperatures. The major diffraction peaks of (111), (211), (221) and (222) plans correspond to cubic pyrite phase (ICCD No. 01-089-3057).
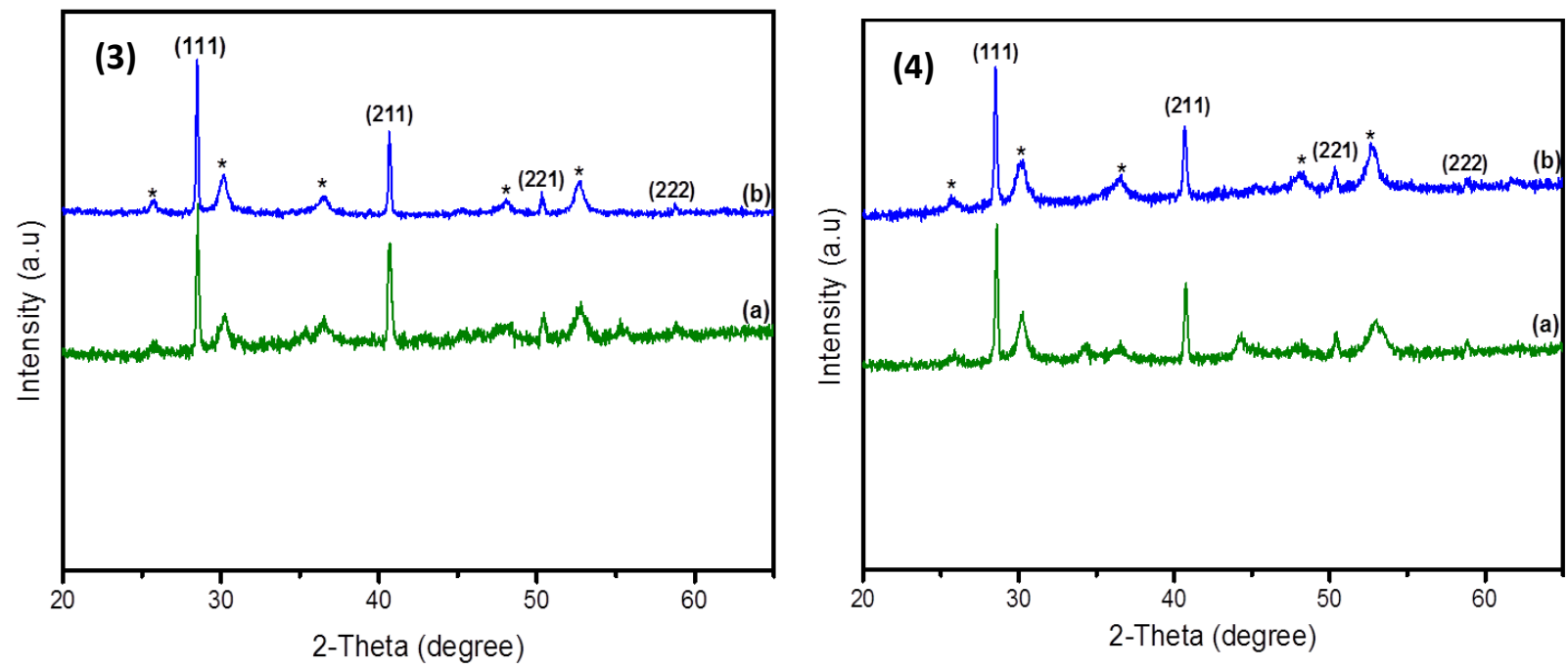

Figure 7. PXRD patterns of the iron sulfide powders obtained by thermolysis method of $\left[\mathrm{Fe}\left(\mathrm{S}_{2} \mathrm{CO}-\left(\mathrm{CH}_{2}\right)_{2} \mathrm{OMe}\right)_{3}\right](3)$ and $\left[\mathrm{Fe}\left(\mathrm{S}_{2} \mathrm{CO}-\left(\mathrm{CH}_{2}\right)_{2} \mathrm{OEt}\right)_{3}\right](4)$, under nitrogen at $250^{\circ} \mathrm{C}$ (a) and $300^{\circ} \mathrm{C}$ (b) for $60 \mathrm{~min}$. The asterisk symbol $\left({ }^{*}\right)$ represent cubic Greigite (ICDD: 00-016-0713).

SEM images of iron sulfide nanostructure powders produced using complexes (1) and (2) as precursors comprised of pseudo spherical like crystallites (Figure 8 (1a-1f)). Flower-like crystallites are observed from powders produced from (3) at temperatures in the range of 200 $-300{ }^{\circ} \mathrm{C}$ (Figure $8(2 \mathrm{a},-2 \mathrm{c})$ ). In contrast, iron sulfide powders produced from complex (4) have no obvious morphology at the resolution offered by SEM (Figure 8 (2d-2f)). No significant changes in morphologies were noticed when the growth temperature was increased. Elemental analysis of nanostructure powder samples of complexes (1) to (4) using EDX spectroscopy were summarised in ESI Table S9.

The obtained structural and morphological results from all precursors using two different routes were summarised in Table 1. There is a massive difference between the results obtained using spin coating and melt thermolysis routes. The p-XRD results obtained from spin coating method result in formation of pyrite with preferred orientation, whereas the mixed phase with randomly oriented nanocrystals?? were observed when thermolysis method is used. Importantly, the approaches demonstrated in this work provide simple, low-cost and 
promising methods to synthesise a variety of nanomaterials?? with different size and morphology.
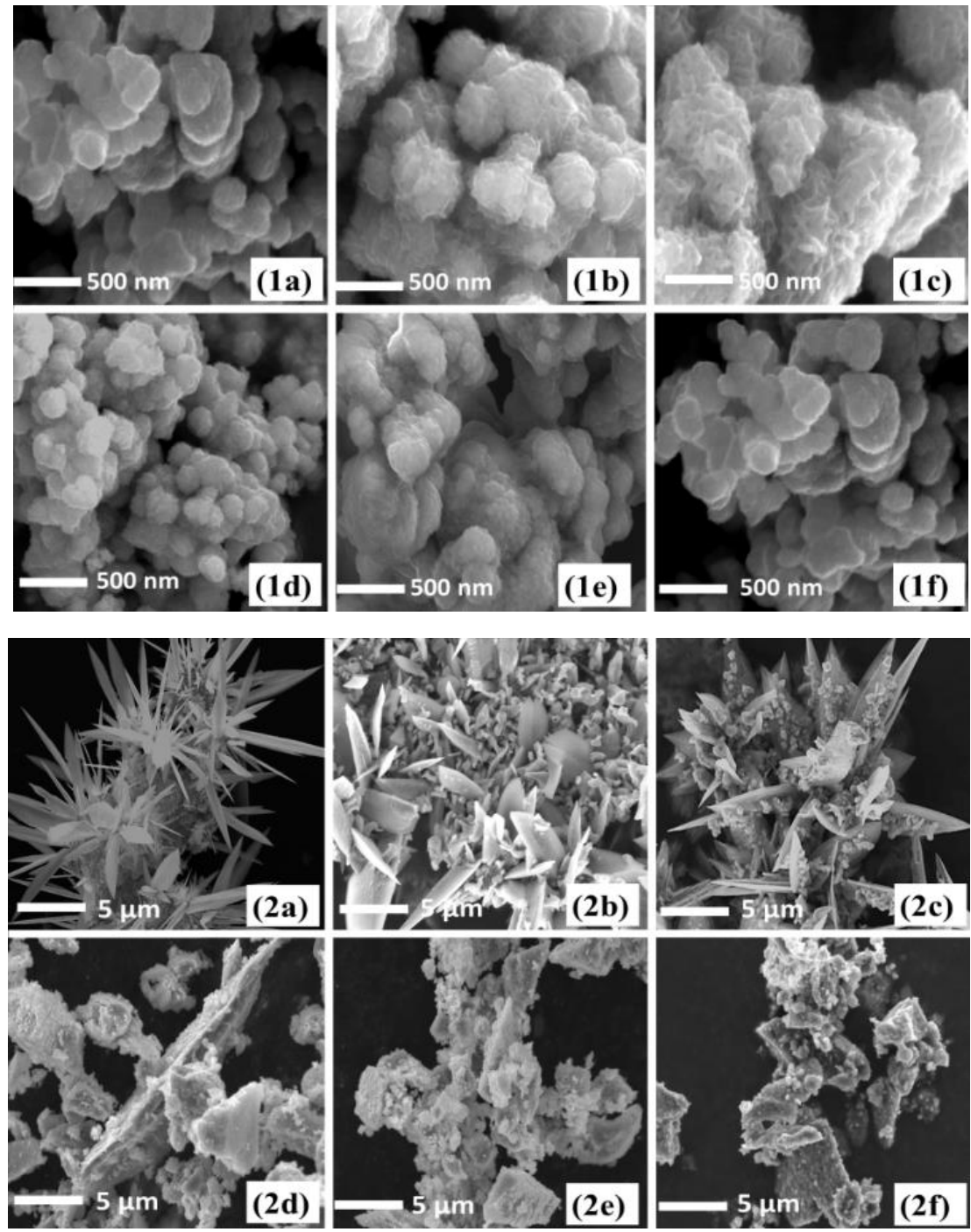

Figure 8. SEM images of iron sulfide powders produced by solventless thermolysis from $\left[\mathrm{Fe}\left(\mathrm{S}_{2} \mathrm{CO} \mathrm{Bu}\right)_{3}\right](1 \mathrm{a})$ at $200{ }^{\circ} \mathrm{C}(1 \mathrm{~b})$ at $250^{\circ} \mathrm{C}$ and $(1 \mathrm{c})$ at $300{ }^{\circ} \mathrm{C},\left[\mathrm{Fe}\left(\mathrm{S}_{2} \mathrm{CO}^{2} \mathrm{Bu}\right)_{3}\right](1 \mathrm{~d})$ at $200{ }^{\circ} \mathrm{C},(1 \mathrm{e})$ at $250^{\circ} \mathrm{C}$ and $(1 \mathrm{f})$ at $\left.300{ }^{\circ} \mathrm{C},\left[\mathrm{Fe}\left(\mathrm{S}_{2} \mathrm{CO}-\left(\mathrm{CH}_{2}\right)_{2} \mathrm{OMe}\right)_{3}\right]\right]$ (2a) at $200^{\circ} \mathrm{C}(2 \mathrm{~b})$ at $250^{\circ} \mathrm{C}$ and $(2 \mathrm{C})$ at 300 ${ }^{\circ} \mathrm{C}$, and $\left[\mathrm{Fe}\left(\mathrm{S}_{2} \mathrm{CO}-\left(\mathrm{CH}_{2}\right)_{2} \mathrm{OEt}\right)_{3}\right](1 \mathrm{~d})$ at $200{ }^{\circ} \mathrm{C}$, (1e) at $250^{\circ} \mathrm{C}$ and $(1 \mathrm{f})$ at $300{ }^{\circ} \mathrm{C}$. 


\begin{tabular}{lcll}
\hline Precursor & $\begin{array}{c}\text { growth } \\
\text { temperature } \\
{ }^{\circ} \mathbf{C}\end{array}$ & $\begin{array}{l}\text { Phase and Morphology obtained } \\
\text { by spin coating method }\end{array}$ & $\begin{array}{c}\text { Phase and Morphology obtained } \\
\text { by thermolysis method }\end{array}$ \\
\hline (1) & 200,250 and 300 & Pyrite ,cubic & $\begin{array}{l}\text { Hexagonal pyrrhotite and Pyrite, pseudo } \\
\text { spherical like crystallites }\end{array}$ \\
(2) & 200,250 and 300 & Pyrite ,cubic & $\begin{array}{l}\text { Hexagonal pyrrhotite and Pyrite, pseudo } \\
\text { spherical like crystallites }\end{array}$ \\
(3) & 200,250 and 300 & $\begin{array}{l}\text { Pyrite and marcasite, } \\
\text { Small crystallites with no defined morphology } \\
\text { Pyrite and marcasite, Semi-cubic }\end{array}$ & Pyrite and greigite, Flower-like crystallites \\
(4) & 200,250 and 300 & $\begin{array}{l}\text { Pyrite and greigite, crystallites with no } \\
\text { obvious morphology }\end{array}$ \\
\hline
\end{tabular}

Table 1. Summary of iron sulfide thin films and nanomaterials obtained from precursors (1) to (4) under different reaction conditions.

\section{Optical properties of iron disulfide thin films}

Figure 9 present the room temperature Ultraviolet-visible-Near Infrared (UV-Vis-NIR) absorption spectra of iron sulfide thin films deposited on glass substrate at three different temperatures $\left(200,250\right.$ and $300{ }^{\circ} \mathrm{C}$ ) for 60 min using a complex (1). These pyrite thin films display light absorbance ranging from the far-UV to near infrared regions of the electromagnetic spectrum. The energy of the direct band gap was estimated from Tauc plots (a plot of $(\alpha h v)^{2}$ versus hv) ${ }^{46}$ with a straight line fitting, with energies of $2.3,1.9$ and $1.6 \mathrm{eV}$ extrapolated at deposition temperatures of 200,250 and $300{ }^{\circ} \mathrm{C}$ respectively. It is clear from the spectra that the evaluated band gap of as-deposited pyrite thin films were significantly influenced by growth temperature, which demonstrates control of optical properties by changing the growth temperature. 


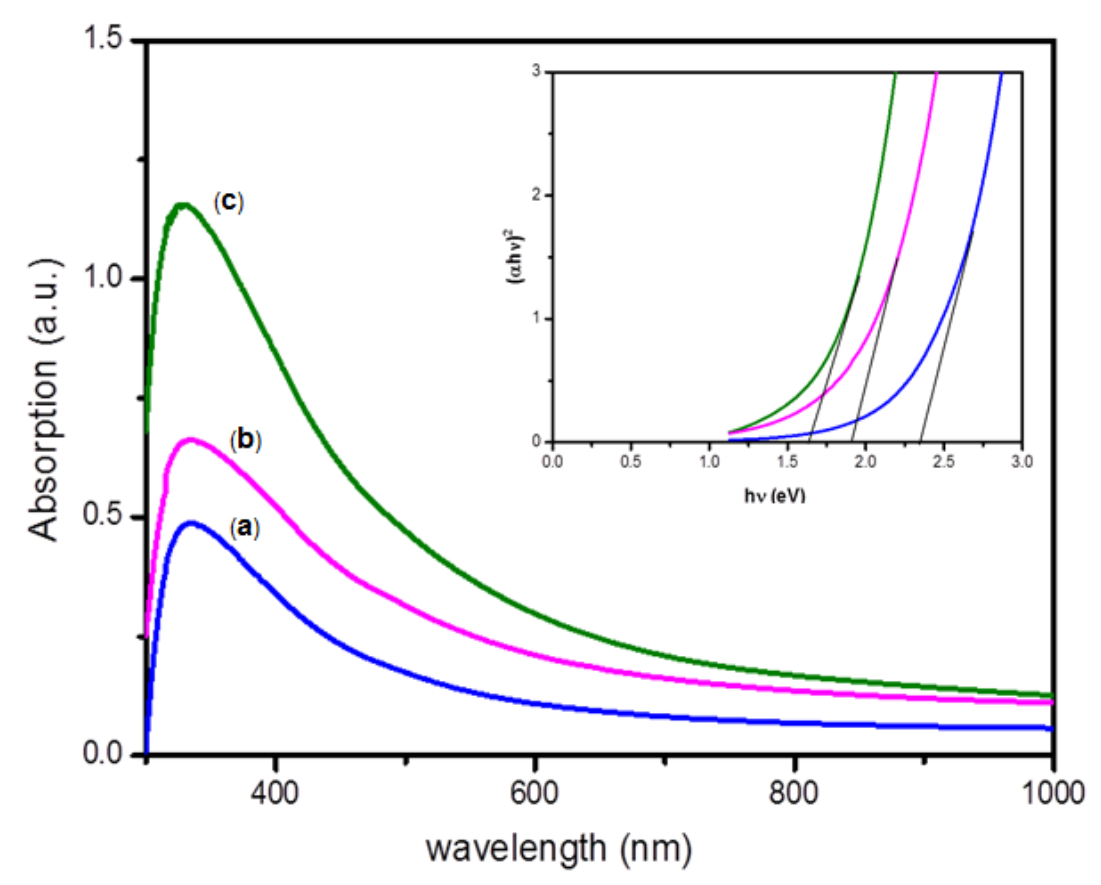

Figure 9. UV-Vis-NIR absorption spectra and band gap plot of pyrite $\left(\mathrm{FeS}_{2}\right)$ thin films deposited from complex (1) on glass substrate at (a) 200, (b) 250 and (c) $300{ }^{\circ} \mathrm{C}$.

These results are consistent with the previously reported literature for pyrite $\left(\mathrm{FeS}_{2}\right) .{ }^{48,49}$ Several reports have been investigated the pyrite band gap at different growth temperatures as represented in Figure 10. For example, a hydrothermal method was used to synthesise pyrite at growth temperature of $120{ }^{\circ} \mathrm{C}$ and the estimated direct band gap was $2.75 \mathrm{eV} .{ }^{50}$ While a direct band gap of $1.22 \mathrm{eV}$ was observed in pyrite produced using spray pyrolysis at a temperature of $350{ }^{\circ} \mathrm{C} .{ }^{51}$ Dip and spin coating method were used to deposit pyrite at 220 and $450{ }^{\circ} \mathrm{C}$ the evaluated band gap was direct with band energy values of 1.38 and $1.24 \mathrm{eV}$ respectively.$^{52,53}$ The variation in the band gap among these studies could be attributed to many factors such as microstrain as well as particle size effects. 


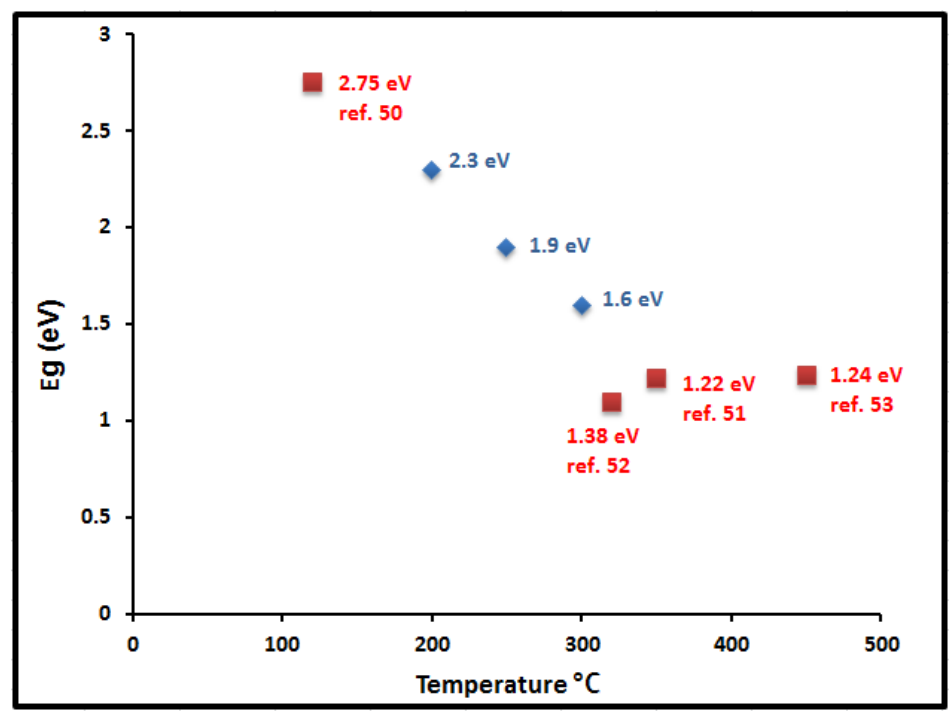

Figure 10. Pyrite band gaps obtained at different growth temperatures. The red data points represent band gap energies reported in literature whereas the data in blue represents the band gap energies reported in this work.

\section{Conclusions}

Novel iron alkyl xanthate complexes have been successfully synthesized and their single crystal X-ray structures elucidated. The as-synthesized complexes were used as single source precursors to deposit iron sulfide thin films and powders?? at different growth temperatures in the range of 200 to $300{ }^{\circ} \mathrm{C}$. The effect of precursor type and deposition temperatures on the structure and morphology of the products have been investigated in details. In general, pure phase of cubic disulfide (pyrite) was deposited from complex (1) and (2) using spin coating technique. Whereas the mixed phases of cubic pyrite $\left(\mathrm{FeS}_{2}\right)$ and hexagonal pyrrhotite $\left(\mathrm{Fe}_{1-\mathrm{x}} \mathrm{S}\right)$ nanostructure were obtained using melt thermolysis approach. In case of complexes (3) and (4), the mixed phases of cubic pyrite and cubic greigite were observed for nanostructure prepared using thermolysis method, whereas a cubic pyrite phase with minor impurities of hexagonal pyrrhotite was obtained for the film prepared using spin coating technique. This leads to two important conclusions. Firstly, the products from spin coating-annealing are generally phase pure materials where the product phase is independent of the precursor used, suggesting that the spin coating technique imposes some kinetic limitation on the growth of other phases in the thin film. Secondly, that solventless thermolysis largely gives different products to spin-coating annealing, in this case phase-separated iron sulfides (e.g. pyrite + greigite), and that synthesis temperature plays a much larger role in the choice of phase 
produced, which may suggest that different reaction pathways are introduced by reaction within a melt as compared to decomposition of thin films of precursors.

\section{References}

1. M.A. Malik, M. Afzaal, P. O’Brien, Chem. Rev., 2010, 110, 4417.

2. H. Geng, L. Zhu, W. Li, H. Liu, L. Quan, F. Xi and X. Su, J.Power Sources, 2015, 281, 204.

3. H. Chen, L. Zhu, H. Liu and W. Li, J. Power Sources, 2014,245, 406.

4. E.-J. Kim, J.-H. Kim, A.-M. Azad and Y.-S. Chang, ACS Appl.Mater. Interfaces, 2011, 3, 1457.

5. X. Qiu, M. Liu, T. Hayashi, M. Miyauchi and K. Hashimoto, Chem. Commun., 2013, 49, 1232-1234.

6. S. A. Kissin and S. D. Scott, Econ. Geol., 1982, 77, 1739.

7. K. Ramasamy, M. A. Malik, N. Revaprasadu and P. O'Brien ,Chem. Mater., 2013, 25, 3551-3569.

8. B.Show, N. Mukherjee and A.Mondal. New J. Chem., 2017, 41, 10083-10095.

9. P. Matthews, M. Akhtar, M. Malik, N. Revaprasaduc and P. O’Brien, Dalton Trans., 2016, 45, 18803.

10. P. Bai, S. Zheng, C. Chen and Hui Zhao, Cryst. Growth Des. 2014, 9, 4295-4302.

11. M. Akhtar, A. L. Abdelhady, M. A. Malik and P. O'Brien, J. Cryst. Growth, 2012, 346, 106-112.

12. Y. Bai, J. Yeom, M. Yang, S.-H. Cha, K. Sun and N. A. Kotov, J. Phys. Chem. C, 2013, 117, 2567-2573.

13. C. Steinhagen, T. B. Harvey, C. J. Stolle, J. Harris and B. A. Korgel, J. Phys. Chem. Lett., 2012, 3, 23522356.

14. S. Shukla, G. Xing, H. Ge, R. R. Prabhakar, S. Mathew, Z. Su,V. Nalla, T. Venkatesan, N. Mathews, T. Sritharan, T. C. Sum and Q. Xiong, ACS Nano, 2016, 10, 4431-4440.

15. A. Kitajou, J. Yamaguchi and S. Hara. J. Power Sources, 2014, 5.247-391.

16. S.Y. Huang, X.Y. Liu, Q.Y. Li, J. Chen, J. Alloys Compd. 2009, 472, 9-12.

17. X. Rui, H. Tan and Q. Yan, Nanoscale, 2014, 6, 9889-9924.Z. Dai, S. Liu, J. Bao and H. Ju, Chem. Eur. J., 2009, 15,4321-4326.

18. Y. Yamaguchi, T. Takeuchi, H. Sakaebe, H. Kageyama,H. Senoh, T. Sakai and K. Tatsumi, J. Electrochem. Soc.,2010, 157, A630-A635.

19. L. Li, M. Cab'an-Acevedo, S. N. Girard and S. Jin., Nanoscale, 2014, 6, 2112-2118

20. Y. Bai, J. Yeom, M. Yang, S.H. Cha, K. Sun, N.A. Kotav,. J. Phys. Chem., 2013, 117, 2567-2573.

21. S. Mlowe, D. J. Lewis, M. A. Malik, J. Raftery, E. B. Mubofu, P. O'Brien and N. Revaprasadu, Dalton Trans., 2016, 45, 2647-2655.

22. G. Smestad, A. Da Silva, H. Tributsch, S. Fiechter, M. Kunst, N. Meziani and M. Birkholz, Sol. Energy Mater., 1989, 18, 299.

23. B. Meester, L. Reijnen, A. Goossens and J. Schoonman, Chem. Vap. Deposition, 2000, 6, 121-128.

24. J. Puthussery, S. Seefeld, N. Berry, M. Gibbs and M. Law, J. Am. Chem. Soc., 2010, 133, 716-719.

25. J.M. Soon, L. Y. Goh, K. P. Loh, Y. L. Foo, L. Ming and J. Ding, Appl. Phys. Lett., 2007, 91, 084-105.

26. G. Smestad, A. Da Silva, H. Tributsch, S. Fiechter,M. Kunst, N. Meziani and M. Birkholz, Sol. Energy Mater.,1989, 18, 299-313.

27. K. Ramasamy, M. A. Malik, M. Helliwell, F. Tuna and P. O’Brien., Inorg. Chem., 2010, 49, 84958503.

28. S. Mlowe, N. S. E. Osman, T. Moyo, B. Mwakikunga and N. Revaprasadu, Mater. Chem. Phys., 2017, 198, 167-176.

29. M. Akhtar, J. Akhter, M. A. Malik, P. O'Brien, F. Tuna, J. Rafterya and M. Helliwella., J. Mater. Chem., 2011, 21, 9737-9745.

30. S. Khalid, E. Ahmed, M. Azad Malik, D. J. Lewis, S. Abu Bakar, Y. Khan and P. O’Brien, New J. Chem., 2015, 39,1013-1021.

31. Q. Xuefeng, X. Yi and Q. Yitai, Mater. Lett., 2001, 48, 109-111. 
32. W. L. Liu, X. H. Rui, H. T. Tan, C. Xu, Q. Y. Yana and H. H. Hng, RSC Adv., 2014,4, 4877048776

33. G. Kaur, B. Singh, P. Singh, M. Kaur, K. Buttar, K. Singh, A. Thakur, R. Bala, M. Kumare and A. Kumar, RSC Adv., 2016, 6, 99120-99128.

34. W. Han and M. Gao, Cryst. Growth Des., 2008, 8,1023-1030.

35. B. Li, L. Huang, M. Zhong, Z. Wei and J. Li, RSC Adv., 2015, 5, 91103.

36. P. V. Vanitha and P. O'Brien, J. Am. Chem. Soc., 2008, 130, 17256.

37. L. Almanqur, I. Vitorica-yrezabal, G. Whitehead, D. Lewis and P. O'Brien, RSC Adv., 2018, 8, 29096.

38. Rigaku Oxford Diffraction, CrysAlisPro Software system, version 1.171.39.30c, Rigaku Corporation, Oxford, UK, 2017.

39. G. M. Sheldrick, Acta Crystallogr., 2015, 71, 3-8.

40. O. V. Dolomanov, L. J. Bourhis, R. J. Gildea, J. A. K. Howard and H. J. Puschmann, Appl. Crystallogr., 2009, 42, 339-341.

41. E. A. Lewis, P. D. McNaughter, Z. Yin, Y. Chen, J. R. Brent, S. A. Saah, J. Raftery, J. A. Awudza, M. A. Malik, P. O'Brien and S. J. Haigh, Chem. Mater., 2015, 27, 2127-2136.

42. B. Abrahams, B. Hoskins, E. Tiekink and G. winter., Aust. J. Chem., 1988, 41, 11 17-22.

43. A. Edwards, B. Hoskins and G.Winte, Aust. J. Chem., 1986, 39, 1983.

44. M. D. Khan, S. Hameed, N. Haider, A. Afzal, M. C. Sportelli, N. Cioffi, M. A. Malik and J. Akhtar, Mater. Sci. Semicond. Process., 2016, 46, 39-45.

45. B. Yuan, W. Luan and S. Tu, Dalton Trans, 2012, 41, 772-776.

46. J. Tauc and A. Menth, J. Non-Cryst. Solids, 1972, 10, 569-585.

47. B. Show, N. Mukherjee and A. Mondal., New J.Chem., 2017, 41, 10083-10095.

48. P. Altermatt, T. Kiesewetter, K. Ellmer, H. Tributsch, Energy Mater. Sol. Cells, 2002, 71, 181-195.

49. J.Suroshe, S. Mlowe, S. Garje and N. Revaprasadu, J. Inorg. Organomet. Polym. Mater., 2018, 28, 603611.

50. S. Middya, A. Layek, A. Dey, P. Pratim Ray., J. Mater. Sci. Technol., 2014, 8, 30.

51. R. H. Misho and W. A. Murad, Sol. Energy Mater. Sol. Cells, 1992, 27.4, 335-345.

52. Y. Bi, Y. Yuan, C. L. Exstrom, S. A. Darveau and J.Huang, Nano Lett., 2011, 11, 4953-4957

53. D. G. Moon, A. Cho, J. H. Park, S. Ahn, H. Kwon, Y. Chob and S. Ahn, J. Mater. Chem. A, 2014, 2, 1777917786. 